\title{
Effect of environmental conditions on species composition of macrophytes - study from two distinct biogeographical regions of Central Europe
}

\author{
R. Hrivnák ${ }^{(1), \star}$, H. Ot'ahel'ová(1), J. Kochjarová(2), P. Pal'ove-Balang ${ }^{(3)}$ \\ Received May 24, 2013
}

Revised August 10, 2013

Accepted August 20, 2013

Key-words:

lotic and lentic ecosystems, Slovakia, aquatic plants, ecologymacrophyte assemblage relationships, aquatic habitats

\section{ABSTRACT}

The relationship between macrophytes and environmental conditions of lotic and lentic habitats was studied within two distinct biogeographical regions (Pannonian and Carpathian) represented by two model areas (Borská nížina lowland and Turčianska kotlina basin) in 2011. Altogether, 72 taxa of macrophytes were found within both studied biogeographical regions, while almost a third of them grew only in one from the regions. Species-environmental variables relationship was studied by Canonical Correspondence Analysis (forward selection), which revealed that three and seven environmental variables explaining $10.35 \%$ and $24.45 \%$ of variance of species data had significant effect on species composition of macrophytes in the Pannonian and Carpathian region, respectively. Flow regime and the portion of fine substrate on the bottom are the main drivers of species composition-environmental condition relationships and explained $3.57 \%$ and $6.21 \%$ of variance in the Pannonian and Carpathian region, respectively. However, the highest values of pure effect on species composition was detected in case of Altitude (Pannonian region; 3.81\%) and Connectivity (Carpathian region; 3.19). Based on the variation partitioning, landscape variables (including geographical variables; Pannonian region; 6.8\%) and hydrological variables (including morphological variables of the bottom; Carpathian region; $11.3 \%$ ) explained a bigger portion of the variability of macrophytes in regions than the other groups of environmental variables.

\section{RÉSUMÉ}

Effet des conditions environnementales sur la composition spécifique de macrophytes étude de deux régions biogéographiques distinctes de l'Europe centrale

\author{
Mots-clés : \\ écosystèmes \\ lotiques \\ et lentiques, \\ Slovaquie,
}

\begin{abstract}
La relation entre les macrophytes et les conditions environnementales des habitats lotiques et lentiques a été étudiée dans deux régions biogéographiques distinctes (Pannonie et Carpates) représentées par deux zones modèles (la plaine Borská Nizina et le bassin kotlina Turčianska) en 2011. Au total, 72 taxons de macrophytes ont été trouvés dans les deux régions biogéographiques étudiées, tandis que près d'un tiers d'entre eux ne pousse que dans une seule des régions. La relation des variables espèce-environnement a été étudiée par analyse canonique des correspondances, qui a révélé que trois et sept variables environnementales expliquant $10,35 \%$ et $24,45 \%$ de la variance des données sur les espèces ont
\end{abstract}

(1) Institute of Botany, Slovak Academy of Sciences, Dúbravská cesta 9, 84523 Bratislava, Slovakia

(2) Botanical Garden, Comenius University, Blatnica 315, 03815 Blatnica, Slovakia

(3) Institute of Biological and Ecological Sciences, University of P. J. Šafárik, Mánesova 23, 04001 Košice, Slovakia

* Corresponding author: richard.hrivnak@savba.sk 
plantes

aquatiques,

relations

d'assemblage

des

macrophytes,

habitats

aquatiques un effet significatif sur la composition des espèces de macrophytes dans les régions de Pannonie et des Carpates, respectivement. Le régime hydrologique et la portion de substrat fin sur le fond sont les principaux moteurs des relations environnement-composition spécifique et expliquent $3,57 \%$ et $6,21 \%$ de la variance dans les régions de Pannonie et des Carpates, respectivement. Toutefois, les valeurs les plus élevées de pur effet sur la composition des espèces ont été détectées dans le cas de l'altitude (région de Pannonie; 3,81\%) et de la connectivité (région des Carpates; 3,19). Basé sur le partitionnement de variation, les variables du paysage (y compris les variables géographiques; région de Pannonie; 6,8 \%) et des variables hydrologiques (y compris les variables morphologiques du fond; région des Carpates; 11,3\%) expliquent une plus grande partie de la variabilité des macrophytes dans les régions que l'autre groupe de variables d'environnement.

\section{INTRODUCTION}

Response of aquatic plants to environmental factors has been a relatively frequently discussed problem during the last decades (Lacoul and Freedman, 2006; Bornette and Puijalon, 2011). Aquatic plants are influenced by factors inherent mainly in the limnology of water habitats, including physical characteristics, such as geomorphology, substrate, climate, and hydrology, as well as biological interactions (Lacoul and Freedman, 2006). Existing studies showed that aquatic plants are synergically influenced by several factors with cross-linked effects. A substantial part of published studies focused on the effect of environmental variables on only one aquatic habitat type. There are several studies coming from lentic habitats (e.g. Toivonen and Huttunen, 1995; del Pozo et al. 2011; Svitok et al., 2011). Similarly, the relationships between environmental variables and species composition were studied in lotic habitats, quite frequently in big rivers (e.g. Onaindia et al., 2005; Gecheva et al., 2013). Fewer studies were conducted in small lotic habitats, e.g. streams and canals (e.g. Riis et al., 2000; Dorotovičová, 2013; Manolaki and Papastergiadou, 2013). Only sporadically, the effect of environmental variables on species composition was studied across various aquatic habitats (Williams et al., 2004).

Heterogeneous environment of Slovakia, which undoubtedly influences the vegetation, provides suitable conditions for the study of the relationship between aquatic macrophytes and environmental variables within two biogeographical regions. The Pannonian and the Carpathian region markedly differ from each other from several points of view; e.g. distinct climate, geological characteristics or human impact. Existing data on aquatic vegetation showed differences between the mentioned regions (Ot'ahel'ová, 1995a, b). Chosen model sites, namely the Borská nížina lowland and the Turčianska kotlina basin, belong to areas relatively well documented by aquatic vegetation studies (e.g. Ot'ahel'ová et al., 1994; Bernátová et al., 2006; Ot'ahel'ová and Ot'ahel', 2006; Hrivnák and Kochjarová, 2008). Because numerous and diverse aquatic habitats are present in both selected model areas, they are sufficiently representative for the studied biogeographical regions and allow generalization of our results for a broader region of Central Europe. The aim of this study was to detect which environmental variables are responsible for species composition in two different biogeographical regions regardless of aquatic habitats. We supposed that the differences in ecological conditions and, consequently, aquatic vegetation in the studied biogeographical regions will be demonstrated by different environmental variables influencing species composition of macrophytes.

\section{STUDY SITES}

Two distinct biogeographical units were chosen for the study: the Turčianska kotlina Basin and the Borská nížina Lowland belonging to the Carpathian and Pannonian biogeographical regions (Figure 1), respectively (Futák, 1966). The Turčianska kotlina basin is situated in the northern part of Central Slovakia, close to mountains, while the Borská nižina Lowland is located in South-Western Slovakia and open to the Pannonian lowland. The Turčianska kotlina 


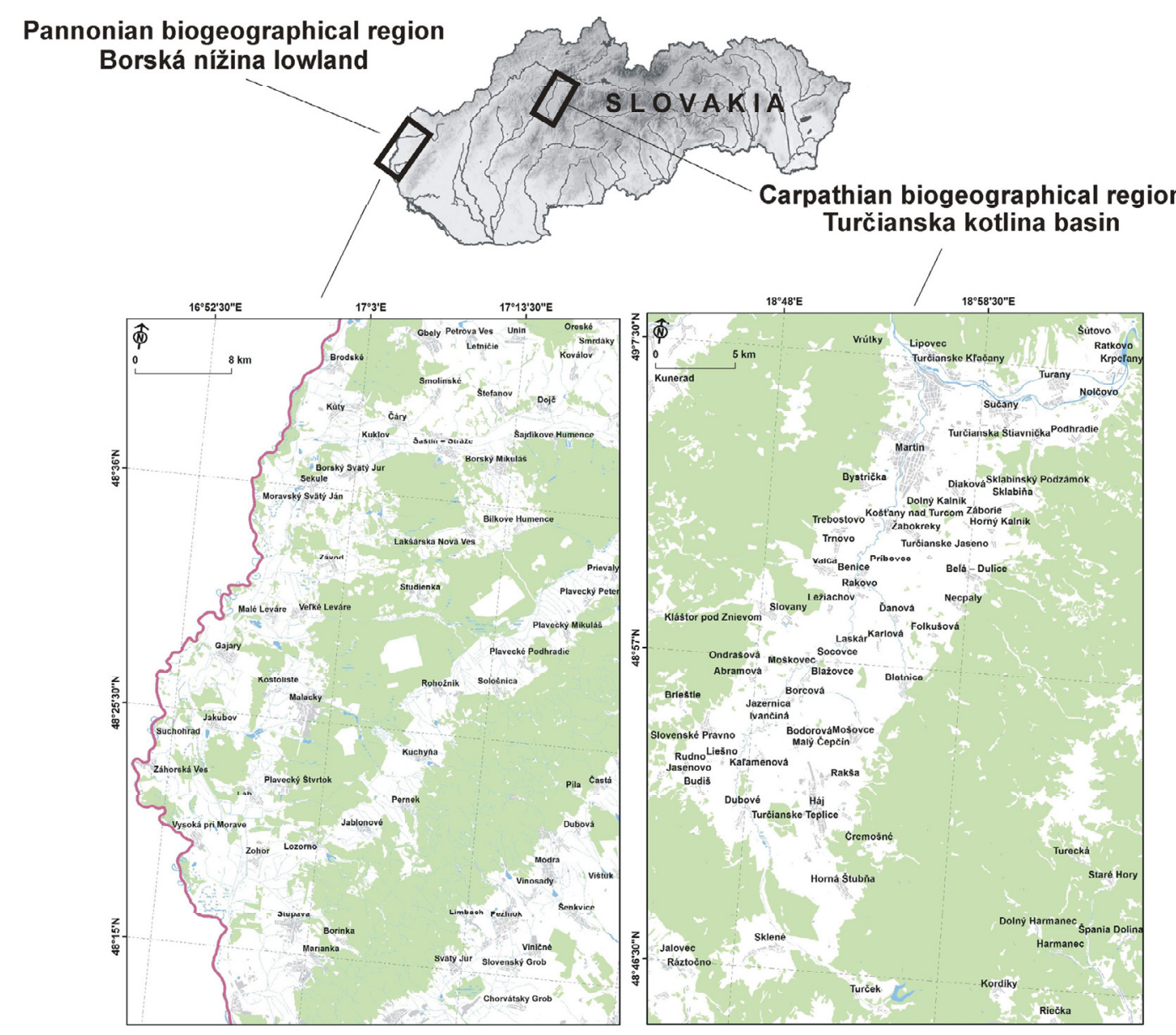

\section{Figure 1}

Map of the studied area.

basin is colder and the amount of annual precipitation is higher than in the case of the Borská nižina lowland. Turčianska kotlina Basin belongs to the moderately warm region and humid to very humid subregion, with mean July temperature and mean annual precipitation totals of 14-16 ${ }^{\circ} \mathrm{C}$ and $800-900 \mathrm{~mm}$, respectively. On the contrary, Borská nižina Lowland represents a warm, moderately dry to semi-humid subregion, where mean July temperature and mean annual precipitation totals are $18-20^{\circ} \mathrm{C}$ and $500-600 \mathrm{~mm}$, respectively (Miklos, 2002).

All types of aquatic habitats with potential occurrence of macrophytes, namely rivers, streams, ditches and ponds (next only habitat types), were studied in both regions. Rivers and streams are habitats created mainly by natural processes and they can be characterised as larger (width more than $8 \mathrm{~m}$ ) or smaller (width less than $8 \mathrm{~m}$ ) lotic waterbodies, respectively. Ditches are man-made lotic waterbodies characterised by a more or less linear form. They have been created primarily for agricultural or industrial purposes, and are thus also characterised by a lesser relationship to the natural landscape. Ponds are lentic waterbodies, including both man-made and natural biotopes, such as reservoirs, gravel and sand pits, fishponds or river oxbows (cf. Williams et al., 2004).

\section{METHODS}

\section{> FIELD SAMPLING}

In total, 160 sampling sites were visited within the studied regions (80 per region). Half of them were studied in the early summer (June) and the second part in the late summer (August and 
September) of 2011 in both regions, intended to suppress seasonal effects of the vegetation. Sampling sites were selected with respect to geographical, geological and altitudinal variability from all potential sites and subsequently stratified by habitat type (20 sites per region). Sampling area of $100 \mathrm{~m}^{2}$ was evaluated in each sampling site. This sampling area was determined as length $x$ width of the watercourse in the case of lotic habitat types. In the ponds, the area was defined as approximately triangular with the apex at the middle of the waterbody and the base following the waterbody margin (cf. Williams et al., 2004). Considering the specified sampling area, small ponds were excluded from potential study sites.

All macrophytes (i.e. macroscopic algae, Charophytes, bryophytes and vascular plants; cf. Janauer and Dokulil, 2006) were recorded at each locality by walking along the bank in shallow water or by boat. Relative abundance of each species was evaluated as the percentage of cover. Nomenclature of taxa follows the Slovak check-list (Marhold and Hindák, 1998).

Simultaneously, following environmental variables were measured or estimated at each sampling site (Table I), as follows: altitude by Garmin GPSmap 62 (Altitude), shading by woody vegetation on banks as the cover of tree and shrub layers (Shading), percentage portion of five basic landscape structures (Forests, Wetlands, Meadows, Fields, and Artificial) in the surrounding landscape (up to a distance of $100 \mathrm{~m}$ from the sampling site), water depth taken at 10 places, randomly scattered over the sampling site; average, minimum and maximum water depth were subsequently calculated (W_depth_ave, W_depth_min and W_depth_max), percentage portion of bottom substrate, classified into 4 categories (S_fine = fine material including both inorganic and organic substrates, S_sand = sand, S_gravel = gravel, and S_coars = rock and large artificial material; $c f$. Janauer, 2003), water reaction (W_pH), water temperature (W_temp), water conductivity (W_cond) and water redox potencial (W_redox) by CyberScan PC 650, type of water regime with respect to several years observation (categories follow from 1 = permanently waterlogged to 4 = dried every year; W_regime), flow velocity class (from $1=$ still to 4 = high flow; Flow; cf. Janauer, 2003), type of connectivity (from 1 = main channel to 3 = separated oxbow), turbidity based on three observations in summer of 2011 (ranked from 1 = clear to 4 = turbid), natural type of origin of habitat type (Origin_n as a binary variable) and presence of bank with gentle slope (Bank_gradual as a binary variable). For chemical analysis in the laboratory, water samples were collected from each sampling site, quickly frozen and maintained at $-18{ }^{\circ} \mathrm{C}$, until ammonia, nitrite, nitrate, and phosphate contents were measured. Substrate material samples were collected randomly in 3 places in each locality intended to reduce the substrate heterogeneity, and mixed to form a single sample per plot that was dried at room temperature until analysis.

\section{$>$ CHEMICAL ANALYSES OF WATER}

Ammonia content was determined by the Nessler's method, using Hanna Instruments standard kit (HI 93715) and following the handbook. Nitrite content was determined spectrophotometrically at $\lambda=540 \mathrm{~nm}$, after diazotation with $40 \mathrm{~g} \cdot \mathrm{L}^{-1}$ sulfanilamide and $2 \mathrm{~g} \cdot \mathrm{L}^{-1}$ $\mathrm{N}$-(1-naphthyl)-ethylenediamine dihydrochloride in $10 \% \mathrm{H}_{3} \mathrm{PO}_{4}$. Nitrate plus nitrite level in the samples was measured by the same method except that the samples were reduced with $1,4 \mathrm{~g} \cdot \mathrm{L}^{-1}$ hydrazinsulphate, $7.5 \mathrm{~g} \cdot \mathrm{L}^{-1} \mathrm{CuSO}_{4}$ and then neutralised adding $3 \mathrm{~g} \cdot \mathrm{L}^{-1} \mathrm{NaOH}$ prior to the diazotation. The nitrate content was then calculated as the difference in the absorbance of the same sample with and without reduction. The phosphate content was analyzed spectrophotometrically according to the modified method described by Rodriguez et al. (1994), measuring the absorbance of the samples at $\lambda=720 \mathrm{~nm}$, after derivatization with ammoniummolybdate reagent containing $0.1 \mathrm{M}$ sulfamic acid, $0.01 \mathrm{M}$ ammonium molybdate, $0.1 \mathrm{M}$ potassium antimonyl oxide tartarate and $0.1 \mathrm{M}$ ascorbic acid (cf. Hrivnák et al., 2010).

\section{> ANALYSIS OF SUBSTRATE}

Substrate samples were crushed and passed through a $2 \mathrm{~mm}$ sieve to remove large particles. These fine substrate fractions were used for all measurements. Substrate pH (S_pH), 


\section{Table I}

The studied environmental variables with the basic statistical characteristics (mean \pm standard deviation, maximum and minimum) in both biogeographical regions. The assessed variables were compared between the Pannonicum and Carpathicum bioregions using the Mann-Whitney U-test (ns = non-significant, ${ }^{*} P<0.05$, $\left.{ }^{* *} P<0.01,{ }^{* * *} P<0.001\right)$. Environmental variables: ${ }^{1}$ hydrological variables (including morphological bottom variables), ${ }^{2}$ chemical variables, ${ }^{3}$ landscape variables (including geographical variables).

\begin{tabular}{|l|l|l|l|}
\hline Pannonian biogeographical region & Carpathian biogeographical region \\
\hline
\end{tabular}

\begin{tabular}{|c|c|c|c|c|c|c|c|}
\hline Environmental variable & Mean $( \pm$ SD) & Max & Min & Mean ( \pm SD) & Max & Min & $P$ value \\
\hline Quantitative variables & & & & & & & \\
\hline 1'W_depth_ave (cm) & $88,11( \pm 64.9)$ & 285.0 & 7.1 & $56.01( \pm 55.4)$ & 248.0 & 7.5 & $\star \star \star *$ \\
\hline${ }^{1}$ W_depth_min (cm) & $57.92( \pm 39.1)$ & 195.0 & 5.0 & $28.48( \pm 27.6)$ & 110.0 & 4.0 & *** \\
\hline${ }^{1}$ W_depth_max $(\mathrm{cm})$ & $112.28( \pm 82.9)$ & 300.0 & 8.0 & $76.20( \pm 66.6)$ & 300.0 & 5.0 & ** \\
\hline 'S_fine (\%) & $48.9( \pm 4.4)$ & 100.0 & 0.0 & $35.6( \pm 4.0)$ & 100.0 & 0.0 & ns \\
\hline 'S_sand (\%) & $24.2( \pm 3.7)$ & 100.0 & 0.0 & $7.6( \pm 1.4)$ & 70.0 & 0.0 & ns \\
\hline${ }^{1}$ S_gravel (\%) & $13.2( \pm 2.6)$ & 100.0 & 0.0 & $27.6( \pm 3.2)$ & 100.0 & 0.0 & $\star *$ \\
\hline${ }^{1}$ S_coars $(\%)$ & $13.8( \pm 3.0)$ & 100.0 & 0.0 & $28.70( \pm 3.7)$ & 100.0 & 0.0 & * \\
\hline${ }^{2} \mathbf{W} \_\mathrm{pH}$ & $7.87( \pm 0.6)$ & 9.4 & 6.1 & $8.03( \pm 0.4)$ & 8.7 & 6.9 & * \\
\hline${ }^{2} \mathbf{W} \_$temp $\left({ }^{\circ} \mathrm{C}\right)$ & $20.56( \pm 3.2)$ & 28.8 & 14.3 & $15.33( \pm 2.5)$ & 22.1 & 10.1 & *** \\
\hline${ }^{2} \mathrm{~W}_{-}$cond $(\mu \mathrm{S} / \mathrm{cm})$ & $\begin{array}{c}589.36 \\
( \pm 254.4)\end{array}$ & 1445.0 & 128.4 & $\begin{array}{c}457.26 \\
( \pm 143.2)\end{array}$ & 964.4 & 63.5 & 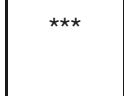 \\
\hline${ }^{2} W_{-}$redox $(\mathrm{mV})$ & $-70.77( \pm 30.1)$ & -12.1 & -164.4 & $-79.28( \pm 21.4)$ & -14.1 & $|-116.7|$ & * \\
\hline${ }^{2} \mathrm{~S}_{-} \mathrm{NH}_{4}^{+}(\mu \mathrm{g} / \mathrm{g})$ & $24.33( \pm 29.2)$ & 163.0 & 2.3 & $37.40( \pm 21.1)$ & 97.7 & 0.0 & 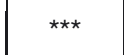 \\
\hline${ }^{2} \mathrm{~S} \_\mathrm{NO}_{3}^{-}(\mu \mathrm{g} / \mathrm{g})$ & $7.52( \pm 11.3)$ & 48.3 & 0.0 & $2.10( \pm 3.0)$ & 13.1 & 0.0 & $\star *$ \\
\hline${ }^{2} \mathrm{~S} \_\mathrm{NO}_{2}^{-}(\mu \mathrm{g} / \mathrm{g})$ & $1.19( \pm 2.7)$ & 20.1 & 0.0 & $0.76( \pm 1.5)$ & 8.9 & 0.0 & ns \\
\hline${ }^{2} \mathrm{~S}_{-} \mathrm{PO}_{4}^{-}(\boldsymbol{\mu g} / \mathrm{g})$ & $109.98( \pm 68.1)$ & 384.7 & 18.9 & $79.40( \pm 58.5)$ & 319.8 & 0.0 & ** \\
\hline${ }^{2} \mathbf{W}_{-} \mathrm{NH}_{4}^{+}\left(\mathrm{mg} \cdot \mathrm{L}^{-1}\right)$ & $0.29( \pm 0.5)$ & 2.3 & 0.0 & $0.12( \pm 0.5)$ & 4.4 & 0.0 & $\star \star \star ~$ \\
\hline${ }^{2} \mathrm{~W}_{-} \mathrm{NO}_{3}^{-}\left(\mathrm{mg} \cdot \mathrm{L}^{-1}\right)$ & $1.74( \pm 2.1)$ & 9.4 & 0.0 & $2.62( \pm 1.7)$ & 6.0 & 0.1 & 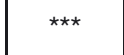 \\
\hline${ }^{2} \mathrm{~W}_{-} \mathrm{NO}_{2}^{-}\left(\mathrm{mg} \cdot \mathrm{L}^{-1}\right)$ & $0.09( \pm 0.1)$ & 0.7 & 0.0 & $0.15( \pm 0.2)$ & 0.6 & 0.0 & $\star *$ \\
\hline${ }^{2} \mathrm{~W}_{-} \mathrm{PO}_{4}^{-}\left(\mathrm{mg} \cdot \mathrm{L}^{-1}\right)$ & $0.34( \pm 0.4)$ & 1.8 & 0.0 & $0.21( \pm 0.3)$ & 1.2 & 0.0 & * \\
\hline${ }^{2} \mathrm{~S} \_$cond $(\mu \mathrm{S} / \mathrm{cm})$ & $\begin{array}{c}902.14 \\
( \pm 719.5)\end{array}$ & 3375.0 & 106.8 & $\begin{array}{c}741.35 \\
( \pm 656.0)\end{array}$ & 4661.0 & 115.3 & ns \\
\hline${ }^{2} \mathrm{~S} \_\mathrm{pH}$ & $7.26( \pm 0.8)$ & 8.3 & 4.3 & $7.71( \pm 0.4)$ & 8.5 & 5.7 & $* * *$ \\
\hline${ }^{2} S \_r e d o x(m V)$ & $-36.72( \pm 47.8)$ & 136.2 & -102.8 & $-61.73( \pm 25.0)$ & 58.1 & -106.7 & 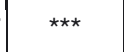 \\
\hline${ }^{3}$ Altitude (m) & $154.94( \pm 18.6)$ & 223.0 & 97.0 & $429.65( \pm 34.2)$ & 551.0 & 374.0 & *** \\
\hline${ }^{3}$ Shading (\%) & $29.71( \pm 37.5)$ & 100.0 & 0.0 & $47.27( \pm 38.8)$ & 100.0 & 0.0 & * \\
\hline${ }^{3}$ Forests (\%) & $25.48( \pm 32.3)$ & 100.0 & 0.0 & $22.06( \pm 26.9)$ & 100.0 & 0.0 & ns \\
\hline${ }^{3}$ Wetlands (\%) & $10.22( \pm 23.5)$ & 99.5 & 0.0 & $5.54( \pm 13.8)$ & 70.0 & 0.0 & ns \\
\hline${ }^{3}$ Meadows (\%) & $23.52( \pm 29.6)$ & 100.0 & 0.0 & $35.90( \pm 32.4)$ & 98.0 & 0.0 & $\star \star$ \\
\hline${ }^{3}$ Fields (\%) & $30.65( \pm 35.1)$ & 100.0 & 0.0 & $18.03( \pm 27.4)$ & 95.0 & 0.0 & ns \\
\hline${ }^{3}$ Artificial (\%) & $10.12( \pm 18.5)$ & 95.0 & 0.0 & $15.52( \pm 25.6)$ & 90.0 & 0.0 & $\mathrm{~ns}$ \\
\hline $\begin{array}{l}\text { Categorial } \\
\text { variables }\end{array}$ & $\begin{array}{l}\text { Prevailing } \\
\text { cathegory }\end{array}$ & & & $\begin{array}{l}\text { Prevailing } \\
\text { cathegory }\end{array}$ & & & \\
\hline${ }^{1} \mathrm{~W}$ _regime & 1. & & & 1. & & & \\
\hline${ }^{1}$ Flow & 2. & & & 3. & & . & \\
\hline${ }^{1}$ Connectivity & 1. & & & 1. & & . & \\
\hline${ }^{1}$ Turbidity & 3. & & . & 2. & & . & . \\
\hline \begin{tabular}{|l} 
Binary \\
variables
\end{tabular} & $\begin{array}{r}\text { Relative } \\
\text { frequency } \\
\text { of variables }\end{array}$ & & & $\begin{array}{r}\text { Relative } \\
\text { frequency } \\
\text { of variable }\end{array}$ & & & \\
\hline $\begin{array}{l}\text { 1Bank_gradual } \\
{ }^{3} \text { Origin_n }\end{array}$ & $\begin{array}{l}18 . \\
15 .\end{array}$ & & . & $\begin{array}{l}27 . \\
27 .\end{array}$ & & . & \\
\hline
\end{tabular}


conductivity (S_cond) and redox potential (S_redox) were measured in distilled water (1:2.5 substrate:water ratio) using CyberScan PC 650 multiparameter device. Nitrate, nitrite and ammonia content was determined in the samples extracted 2 hours with $1 \mathrm{M} \mathrm{KCl}$ and centrifuged $10 \mathrm{~min}$. at $2000 \mathrm{~g}$, by the same methods than used for water analyses. For the determination of extractable phosphate, samples were extracted for $2 \mathrm{~h}$ using Mehlich 3 extraction solution (0.2 $\mathrm{M}$ acetic acid; $0.25 \mathrm{M} \mathrm{NH}_{4} \mathrm{NO}_{3}$; $0.015 \mathrm{M} \mathrm{NH}_{4} \mathrm{~F} ; 0.013 \mathrm{M} \mathrm{HNO}_{3}$ and $0.001 \mathrm{M}$ EDTA). Phosphate was determined by the ammonium molybdate method as described above.

\section{> STATISTICAL TREATMENT}

Species composition-environmental relationship was studied by direct ordination method, Canonical Correspondence Analysis (CCA). First, incompletely documented sampling sites (sites, where no macrophytes were detected or where some environmental variable/s could not be assessed) were excluded. Finally, 65 (rivers $=12$, streams $=17$, ditches $=19$ and ponds $=17$ ) and 71 (rivers $=18$, streams $=17$, ditches $=17$ and ponds $=19$ ) sampling sites were subjected to the analysis in the Pannonian and Carpathian region, respectively. Subsequently, Detrended Correspondence Analysis (DCA) was used to test the applicability of linear or unimodal methods; lengths of gradients were 7.175 and 9.235 in the Pannonian and Carpathian dataset, respectively, which means that the unimodal model is suitable for further analyses in both cases. Based on published data about aquatic vegetation and our expert knowledge, we decided to evaluate the regions separately. However, DCA was used for identification of expected differences in species composition between biogeographical regions as well. Species data were logarithmically transformed in all cases, whereas environmental variables (Table I) were not transformed. Environmental variables best explaining species data variability were identified by forward selection, and their significance was tested by Monte Carlo permutation tests (999 runs). The outcomes of this analysis are presented in the Table II as the conditional effects (cf. Lepš \& Šmilauer 2007). Multicollinearity was tested for all environmental variables included in final models using the variance inflation factor (VIF) according to the recommendations by Meyers et al. (2006). Their significance was modified by sequential Bonferroni correction. The pure effect of individual variables was calculated as a percentage variance explained by individual variables after all variables that were significant when alone were factored out by setting as covariables (ter Braak \& Prentice 1988). Finally, the significant environmental variables were combined together into three categories (see Table I) and their relative effects on the species composition were estimated using variation partitioning (Lepš and Šmilauer, 2007). Differences in environmental variables between the Pannonicum and Carpathicum bioregions were tested using the Mann-Whitney U-test. All statistical analyses were performed in CANOCO 4.5 for Windows package (ter Braak and Šmilauer, 2002) and the STATISTICA software (Statsoft 2001).

\section{RESULTS}

\section{> SPECIES COMPOSITION}

Totally, 72 taxa of macrophytes were found within the studied biogeographical regions; 62 of them belong to vascular plants, 7 are bryophytes and 3 are macroscopic algae (Charophytes). The number of macrophytes was similar in both regions. Most of them were common for both regions, but relatively many species grew only in a single region (Figure 2). More frequent species were Spirodela polyrhiza, Potamogeton nodosus for the Pannonian region, and $\mathrm{Ba}-$ trachium aquatile, $B$. circinatum for the Carpathian region. Among the species, which grew in both regions, Lemna minor, Ceratophyllum demersum, and Potamogeton pectinatus were more frequent in the Pannonian region, as compared to Fontinalis antipyretica, Rhynchostegium riparioides, and Elodea canadensis in the Carpathian region (Figure 2). Specific species 


\section{Pannonian biogeographical region Carpathian biogeographical region}

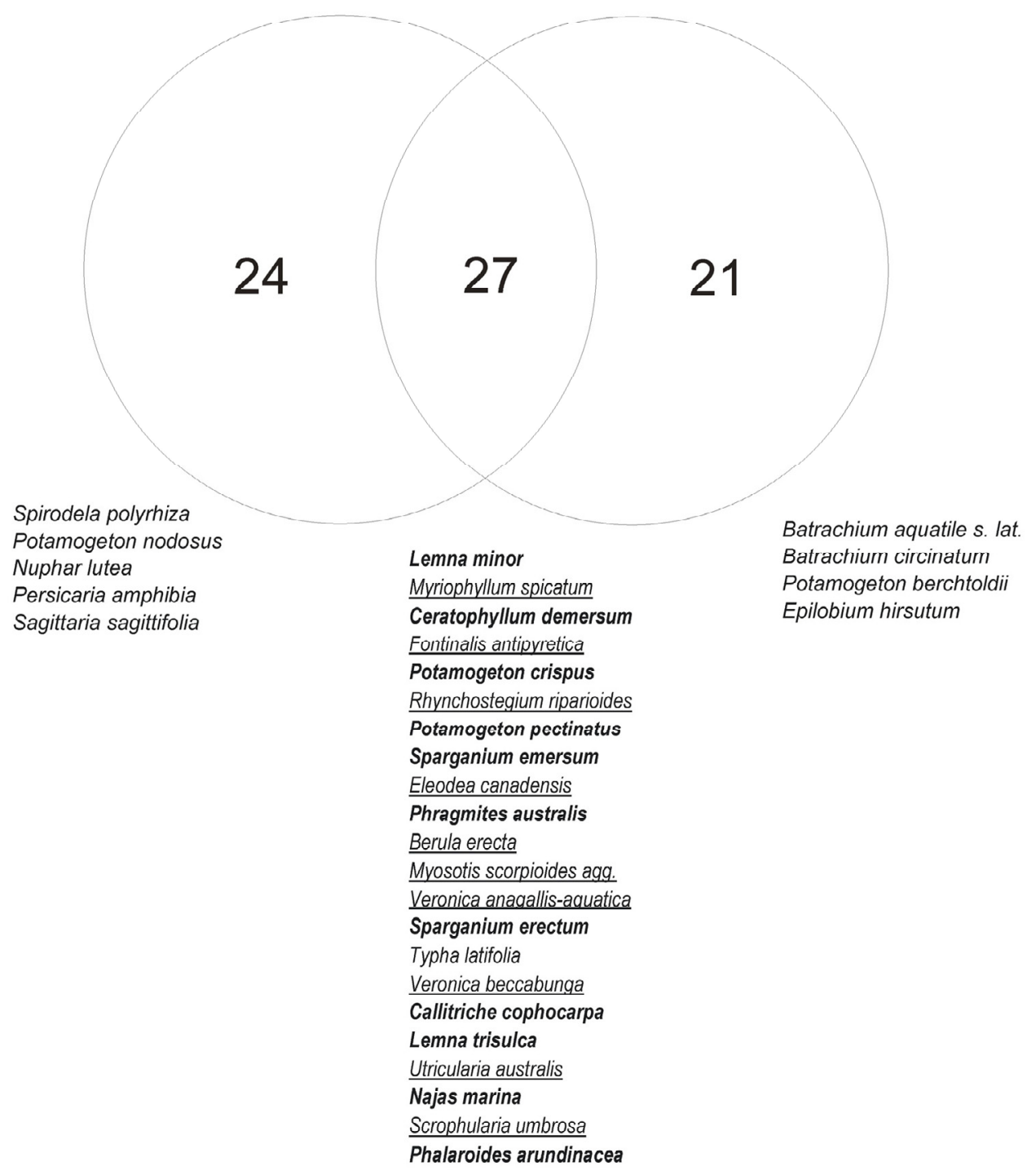

\section{Figure 2}

Species found in individual biogeographical regions and/or in both regions together. Among species occurring in both regions, bold italics is used to designate species with higher frequency in the Pannonian biogeographical region, underlined italics species with higher frequency in the Carpathian biogeographical region and simple italics species with the same frequency in both regions. Only species with the occurrence on at least 5 localities are shown.

studied regions. In contrast, landscape characteristics mostly did not show significant differences (Table I). Markedly higher water temperature and conductivity, and a higher content of nitrate and phosphate in the bed material were detected among chemical variables in the Pannonian region. Higher altitudes, a smaller fraction of wetlands and fields in the adjacent landscape of the aquatic habitats were detected within landscape variables in the Carpathian region. More aquatic habitats had natural origin in Carpathian region, as well.

\section{> SPECIES COMPOSITION-ENVIRONMENTAL VARIABLES RELATIONSHIP}

Species composition in two distinct biogeographical regions was influenced by different environmental factors (Table II, Figures 4 and 5). In the Pannonian region, forward selection 


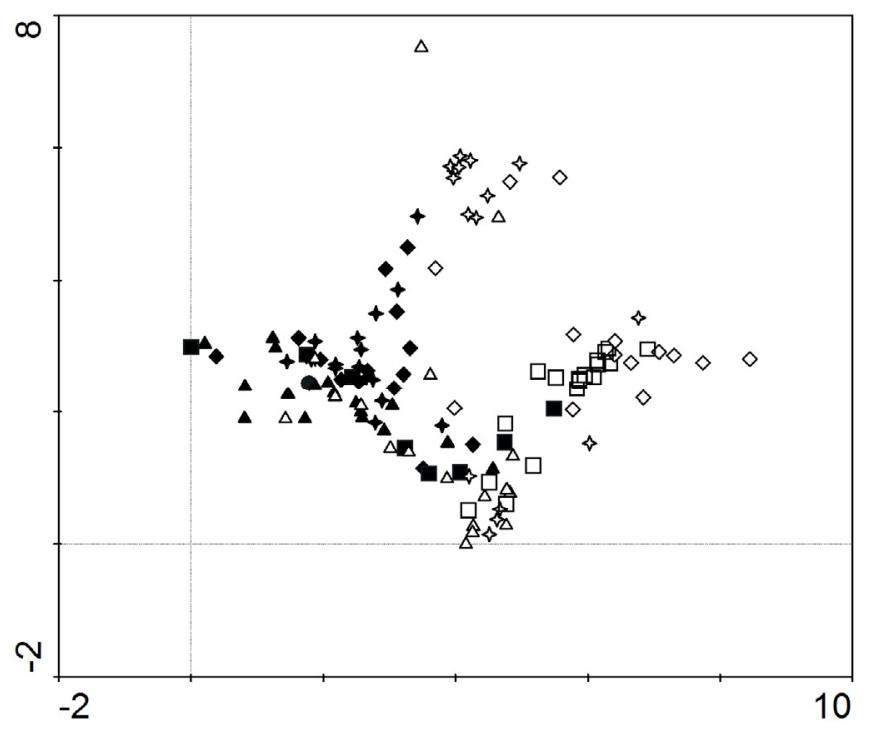

\section{Figure 3}

Ordination diagram (DCA) of sampling site. Black symbols - Pannonian biogeographical region, empty symbols - Carpathian biogeographical region; habitat types: squares - rivers, diamonds - streams, stars - ditches and triangles - ponds.

revealed that three variables were significant and explained $10.35 \%$ of variance. On the contrary, 7 variables had a significant effect on species composition in the Carpathian region and explained twice as much variance $(24.45 \%)$. The values of the variance inflation factors $(<3.5)$ indicated a lack of multicollinearity in the explanatory variables included in the models. Flow velocity (Flow) and the portion of fine bottom substrate (S_fine) explained the highest part of variance (conditional effect) in the Pannonian and Carpathian region, respectively. Altitude and connectivity exhibited the highest pure effect on species composition in the Pannonian and Carpathian bioregions, respectively (Table II). Only one variable significantly affected the species composition in both regions $(P<0.05)$, namely the natural origin of aquatic habitat type (Origin_n).

Landscape variables explained the highest species-environment variability, followed by hydrological variables, in the Pannonian region (Figure $6 \mathrm{~A}$ ). In case of the Carpathian region, the situation was different as the variables were arranged in decreasing order from hydrology over landscape to chemistry (Figure 6B).

\section{DISCUSSION}

Flow velocity class (Flow) was the most important factor influencing species composition of plants in aquatic habitat types in the Pannonian biogeographical region (Table II). This is trivial considering that various aquatic habitats, lentic and lotic, were taken into account. Species composition frequently differed between aquatic habitats with different flow velocity; the presence of macrophytes was shown to depend on different water movement (Daniel et al., 2006; Janauer et al., 2010) or related characteristics, e.g. hydrological connectivity (Ward and Tockner 2001; Demars and Harper, 2005). A fundamental part of European macrophytes is growing in almost still or slowly flowing waters, while only a few aquatic plants are specialised to fast flowing waters (Willby et al., 2000). Fast flowing waters (mainly shallow and small-sized streams) are colonized mainly by bryophytes, which are best adapted for the specific conditions affected by high water flow velocity (Baatrup-Pedersen et al., 2006; Hrivnák et al., 2010). In contrast, vascular aquatic plants grow in all aquatic habitat types, but mainly those with rather still or slowly flowing water (e.g. ponds, reservoirs, canals, bigger and deeper rivers; Willby et al., 2000). These facts are in accordance with our results (Figure 4). 


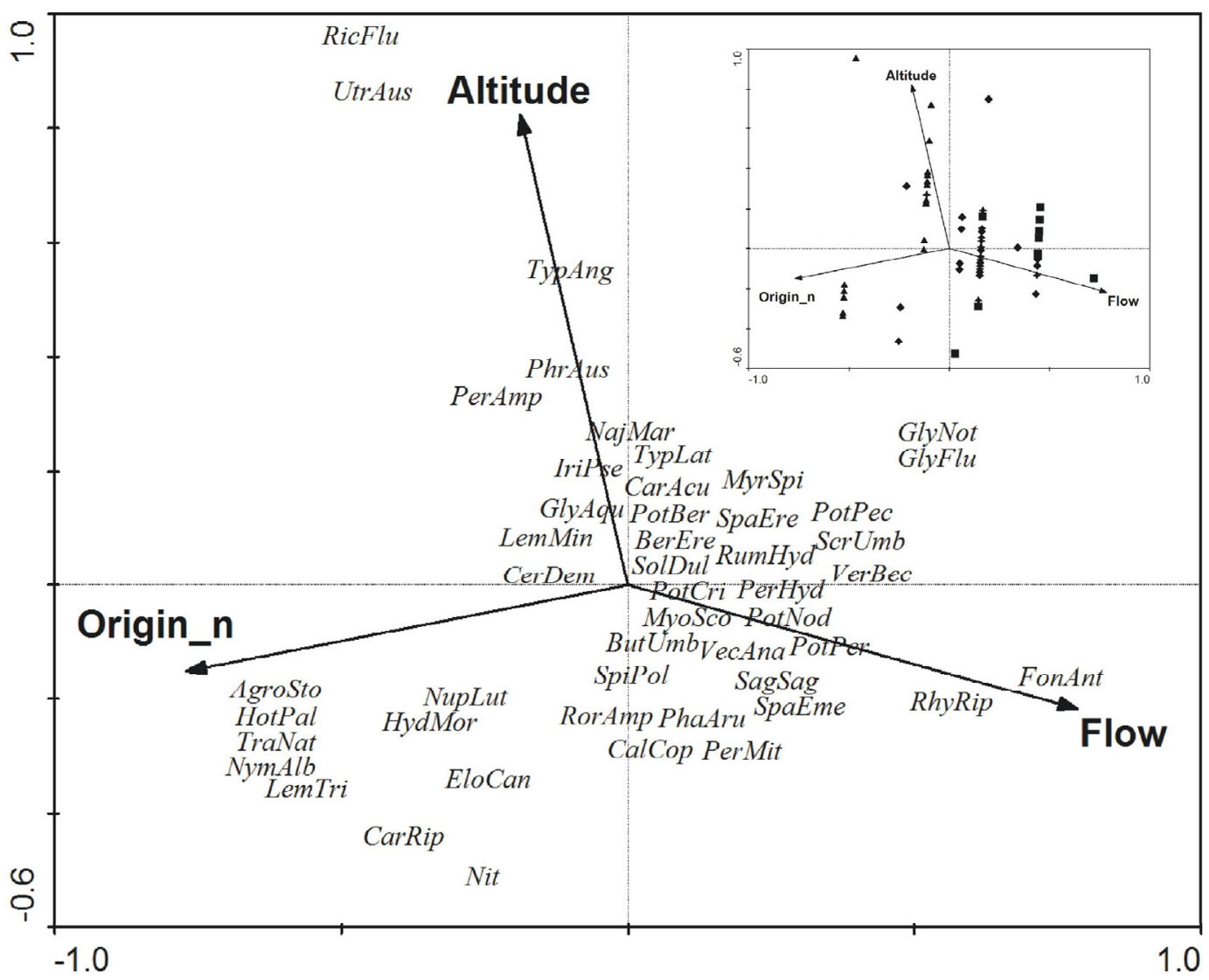

Figure 4

Ordination diagram (CCA) of species and environmental variables in the Pannonian biogeographical region. Only variables with significant effect on species composition in CCA are shown.

Abbreviations of species: AgroSto - Agrostis stolonifera, BerEre - Berula erecta, ButUmb - Butomus umbellatus, CalCop - Callitriche cophocarpa, CarAcu - Carex acutiformis, CarRip - Carex riparia, CerDem Ceratophyllum demersum, EloCan - Elodea canadensis, FonAnt - Fontinalis antipyretica, GlyAqu Glyceria aquatica, GlyFlu - Glyceria fluitans, GlyNot - Glyceria notata, HotPal - Hottonia palustris, HydMor - Hydrocharis morsus-ranae, IriPse - Iris pseudacorus, LemMin - Lemna minor, LemTri - Lemna trisulca, MyoSco - Myosotis scorpioides agg., MyrSpi - Myriophyllum spicatum, NajMar - Najas marina, Nit - Nitella sp., NupLut - Nuphar lutea, NymAlb - Nymphaea alba, PerAmp - Persicaria amphibia, PerMit - Persicaria mitis, PerHyd - Persicaria hydropiper, PhaAru - Phalaroides arundinacea, PhrAus Phragmites australis, PotBer - Potamogeton berchtoldii, PotCri - Potamogeton crispus, PotNod - Potamogeton nodosus, PotPec - Potamogeton pectinatus, PotPer - Potamogeton perfoliatus, RicFlu - Riccia fluitans, RhyRip - Rhynchostegium riparioides, RorAmp - Rorippa amphibia, RumHyd - Rumex hydrolapathum, SagSag - Sagittaria sagittifolia, ScrUmb - Scrophularia umbrosa, SolDul - Solanum dulcamara, SpaEme - Sparganium emersum, SpaEre - Sparganium erectum, SpiPol - Spirodela polyrhiza, TraNat - Trapa natans, TypAng - Typha angustifolia, TypLat - Typha latifolia, UtrAus - Utricularia australis, VerAna - Veronica anagallis-aquatica, VerBec - Veronica beccabunga. For explaining sample symbols see Figure 3.

Water flow was an important factor influencing species composition of macrophytes also in a similar study from England (Williams et al., 2004). Generally, water movement is one of the most important ecological variables influencing macrophyte assemblages in both lentic and lotic aquatic habitats (Lacoul and Freedman 2006; Franklin et al., 2008; Bornette and Puijalon, 2011). The portion of fine bottom substrate (S_fine), closely associated with water movement, explained the highest part of species variability in the Carpathian region (Table II). Species were arranged in the ordination space along the gradient from mainly bryophytes to helophytes and true aquatic plants (Figure 5); similarly as is the case for Flow (Figure 4). Substrate type has frequently been mentioned as a significant ecological factor in rivers (Ferreira and Moreira, 1999; Paal et al., 2007; Franklin et al., 2008). Dynamic water regimes provide 


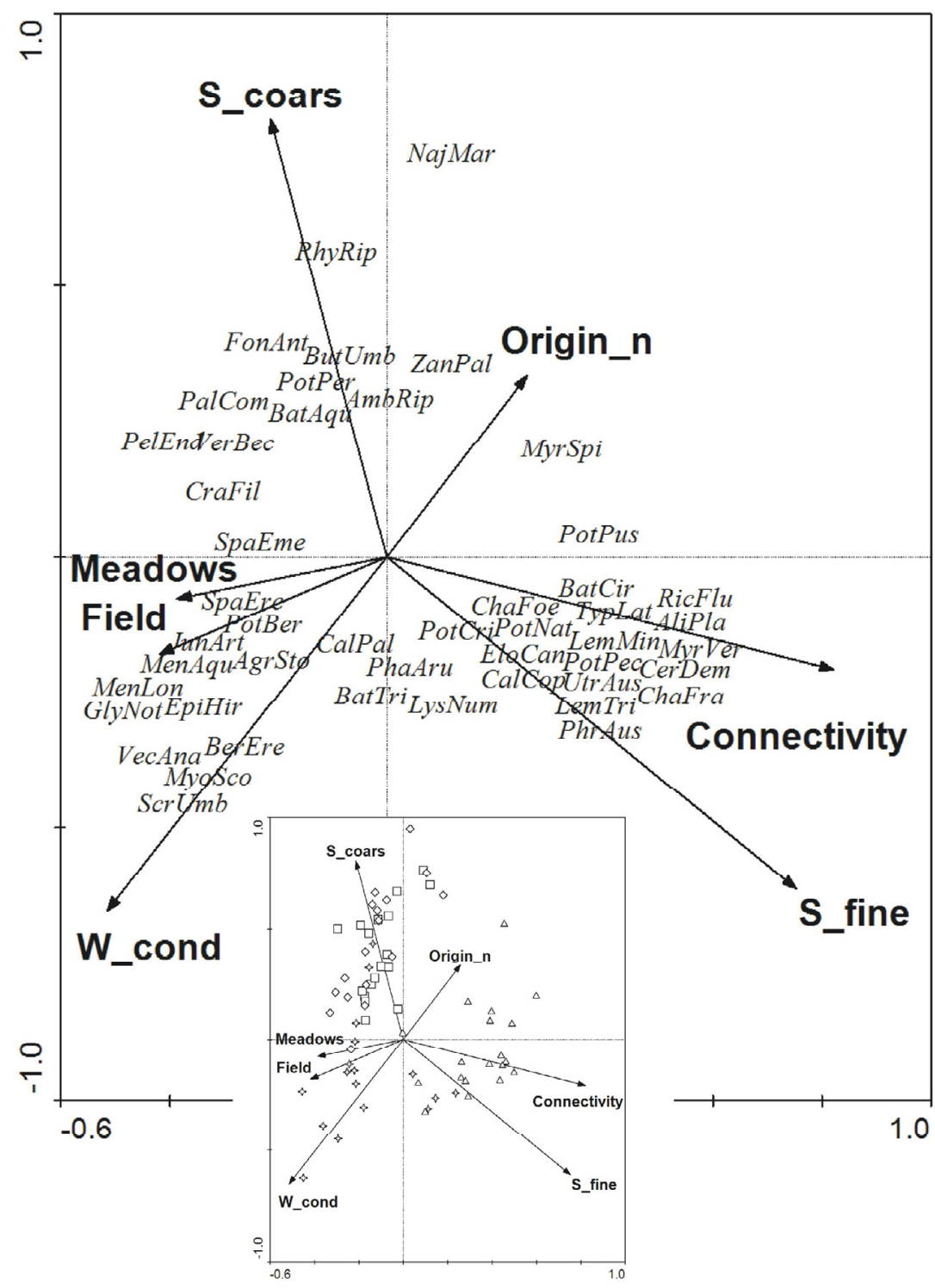

\section{Figure 5}

Ordination diagram (CCA) of species and environmental variables in the Carpathian biogeographical region. Only variables with significant effect on species composition in CCA are shown.

Abbreviations of species: AgroSto - Agrostis stolonifera, AliPla - Alisma plantago-aquatica, AmbRip Amblystegium riparioides, BatAqu - Batrachium aquatile s. lat., BatCir - Batrachium circinatum, BatTri Batrachium trichophyllum, BerEre - Berula erecta, ButUmb - Butomus umbellatus, CalCop - Callitriche cophocarpa, CalPal - Caltha palustris, CerDem - Ceratophyllum demersum, ChaFoe - Chara foetida, ChaFra - Chara fragilis, CraFil - Cratoneuron filicinum, EloCan - Elodea canadensis, EpiHir - Epilobium hirsutum, FonAnt - Fontinalis antipyretica, GlyNot - Glyceria notata, JunArt - Juncus articulatus, LemMin - Lemna minor, LemTri - Lemna trisulca, LysNum - Lysimachia nummularia, MenAqu - Mentha aquatica, MenLon - Mentha longifolia, MyoSco - Myosotis scorpioides agg., MyrSpi - Myriophyllum spicatum, MyrVer - Myriophyllum verticillatum, NajMar - Najas marina, PalCom - Palustriella commutata, PelEnd - Pellia endiviifolia, PhaAru - Phalaroides arundinacea, PhrAus - Phragmites australis, PotBer Potamogeton berchtoldii, PotCri - Potamogeton crispus, PotNat - Potamogeton natans, PotPec - Potamogeton pectinatus, PotPer - Potamogeton perfoliatus, PotPus - Potamogeton pusillus, RicFlu - Riccia fluitans, RhyRip - Rhynchostegium riparioides, ScrUmb - Scrophularia umbrosa, SpaEme - Sparganium emersum, SpaEre - Sparganium erectum, TypLat - Typha latifolia, UtrAus - Utricularia australis, VerAna - Veronica anagallis-aquatica, VerBec - Veronica beccabunga, ZanPal - Zannichellia palustris. For explaining sample symbols see Figure 3. 

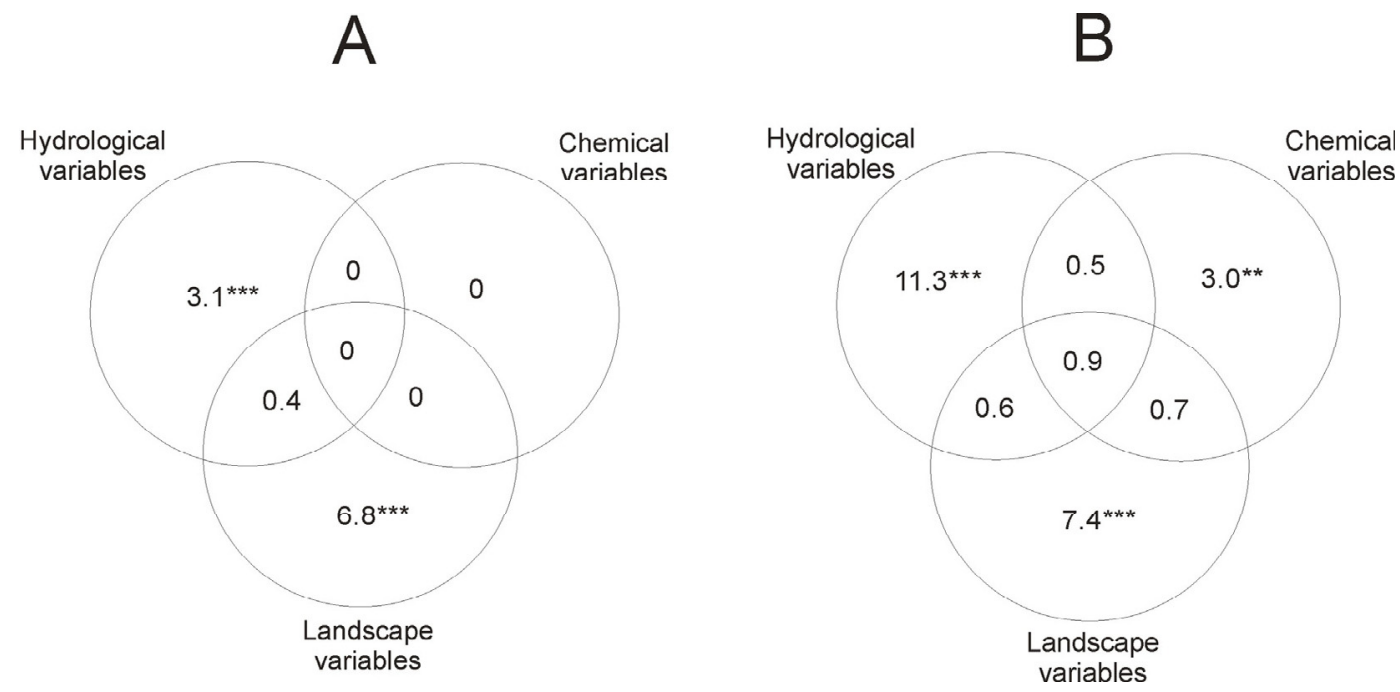

\section{Figure 6}

Venn diagrams of variation partitioning between three groups of environmental variables in the Pannonian (a) and Carpathian (b) biogeographical regions. Total variances explained by all variables are presented in Table II. Significance: ${ }^{* *} p<0.01,{ }^{*} p<0.05$.

a possibility for various bottom substrate types. In the case of still water (e.g. lakes, reservoirs, ponds), finer substrate (organic and inorganic) is more frequent. The heterogeneity of aquatic habitats, from lotic to lentic, is the primary reason why this factor seems to be the most relevant for the spectrum of macrophytes. Both mentioned factors, detected as the most important for species composition in the studied regions, Flow and S_fine belong to the group of hydrological variables and are closely correlated. Statistically significant $(P<0.001)$ relationships between the mentioned characteristics were detected both in the Pannonian and Carpathian region, where the Pearson's correlation coefficients were -0.40 and -0.80 , respectively.

The highest values of pure effect on species composition of macrophytes were found for Altitude and Connectivity in Pannonian and Carpathian regions, respectively (Table II). In case of altitude, our finding is relatively surprising. Generally, altitude is an important driver of species composition of plants, mainly in case of terrestrial vegetation (Rahbek 1995). Aquatic vegetation is impacted by altitude only occasionally and usually on a wide geographical or altitudinal scale (Lacoul and Freedman 2006). In our study, both geographical scale and altitudinal range (only $126 \mathrm{~m}$ including planar and lower colline belts) are small. Hydrological connectivity is an important factor of biodiversity as a result of a complex of physical mechanisms such as water movement, substrate, geo-morphology, chemical effects, for instance enrichment in nutrients, and management in time and space (Bornette et al., 1998; Tockner et al., 1999; Ot'ahel'ová et al., 2007; Sârbu et al., 2011).

Only one variable exhibited equivalent effects on species composition in both studied regions, namely the natural type of origin of the habitat type (Origin_n; Table II). The issue of aquatic habitats of natural origin versus man-made ones and their relationship to macrophyte species composition or diversity belongs to relatively less frequently discussed problems (O'Hare et al., 2006). However, secondary aquatic habitats can represent a suitable place for the existence of many macrophytes including endangered and rare species, mainly when native habitats are disappearing (Dorotovičová 2013). In our study, most of the studied aquatic habitat types had a secondary origin; a major part of natural habitat types was detected in the Carpathian region. In the Pannonian region, this factor contributed more to the explained variability of macrophyte assemblage (Table II).

Within groups of the studied environmental variables, landscape and hydrological variables are the most important for explaining the species composition-environment relationship. Percentage of the variability is relatively similar in landscape variables in both regions, however, 
whereas landscape variables played a more important role in the Pannonian region, hydrological variables were more important in the and Carpathian region (Figure 6A, B). Results from Southern England showed that hydrological variables (both water flow and depth) and geographical variables belong to the most important drivers of wetland plant assemblages (Williams et al., 2004). Results presented in the current study from the studied biogeographical regions are in concordance with the conclusions of the British research. Obviously, hydrological (including morphological bottom variables) and landscape (including geographical variables) can have a more significant influence on species composition-environmental condition relationships than chemical variables, when various aquatic habitat types are taken into account. Based on these two groups of characteristics, which can be assessed more simply than chemical variables, species composition of macrophytes in aquatic habitats can be relatively well predicted.

In spite of the specificity of aquatic vegetation and a relatively small geographical distance of the studied regions, our study showed that aquatic vegetation in different biogeographical regions is influenced by different environmental variables and common affecting ecological factors for these regions are sporadic. Important role in species composition-environmental conditions relationships had mainly landscape and hydrological characteristics, while chemical characteristics were less significant.

\section{ACKNOWLEDGEMENTS}

We would like to thank our colleagues and students, A. Čaja, I. Malina, and Š. Horáčková for their help in the field, D. Treplanová for laboratory works, D. Gömöry and M. Slezák for many consultations and improvement of English. This study was supported by the VEGA Grant Agency (grant no. 2/0004/11) and the Slovak Research and Development Agency under the contract No. APVV-0059-11.

\section{REFERENCES}

Baattrup-Pedersen A. and Riis T., 1999. Macrophyte diversity and compostion in relation to substratum characteristics in regulated and unregulated Danish streams. Freshwater Biol., 42, 375-385.

Baattrup-Pedersen A., Szoszkiewicz, K., Nijboer R., O’Hare M. and Ferreira T., 2006. Macrophyte communities in unimpacted European streams: variability in assemblage patterns, abundance and diversity. Hydrobiologia, 566,179-196.

Bernátová D., Kliment J., Topercer J., Obuch J. and Kučera P., 2006. Aktuálne poznatky o rozšírení niektorých prírodoochranne významných taxónov cievnatých rastlín, machorastov a chár v Turčianskej kotline. Ochr. Prír. , 25, 50-96.

Bornette G. and Puijalon S., 2011. Response of aquatic plants to abiotic factors: a review. Aquat. Sci., 73, 1-14.

Bornette G., Amoros C. and Lamouroux N. 1998. Aquatic plant diversity in riverine wetlands: The role of the connectivity. Freshwater Biol., 39, 267-283.

Chen P.S., Toribara T.Y. and Warner H., 1956. Microdetermination of phosphorus. Anal. Chem., 28, 1756-1758.

del Pozo R., Fernandez-Alaez C. and Fernandez-Alaez M., 2011. The relative importance of natural and anthropogenic effects on community composition of aquatic macrophytes in Mediterranean ponds. Mar. Freshwater Res., 62, 101-109.

Daniel H., Bernez I. and Haury J., 2006. Relationships between macrophytic vegetation and physical features of river habitats: the need for a morphological approach. Hydrobiologia, 570, 11-17.

Demars B.O.L. and Harper D.M. 2005. Distribution of aquatic vascular plants in lowland rivers: Separating the effects of local environmental conditions, longitudinal connectivity and river basin isolation. Freshwater Biol., 50, 418-437.

Dorotovičová C., 2013. Man-made canals as a hotspot of aquatic macrophyte biodiversity in Slovakia. Limnologica, 43, 277-287. 
Ferreira M.T. and Moreira I.S., 1999. River plants from an Iberian basin and environmnetal factors influencing their distribution. Hydrobiologia, 415, 101-107.

Franklin P., Dunbar M. and Whitehead P., 2008. Flow controls on lowland river macropyhtes: A review. Sci. Total Environm., 400, 369-378.

Futák J., 1966. Fytogeografické členenie. In: Futák J. (ed.), Flóra Slovenska I. Vydavatel’stvo Slovenskej akadémie vied, Bratislava, 533-538.

Gecheva G., Yurukova L. and Cheshmedjiev S., 2013. Patterns of aquatic macrophyte species composition and distribution in Bulgarian rivers. Turk. J. Bot., 37, 99-110.

Hrivnák R. and Kochjarová J., 2008. Rastlinné spoločenstvá vôd a močiarov Vel'kej Fatry a pril'ahlej časti Turčianskej kotliny. Bull. Slov. Bot. Spoločn., 30, 261-278.

Hrivnák R., Ot'ahel'ová H., Valachovič M., Pal'ove-Balang P. and Kubinská A., 2010. Effect of environmental variables on the aquatic macrophyte composition pattern in streams: a case study from Slovakia. Fundam. Appl. Limnol., 177, 115-124.

Janauer G.A., 2003. Methods. In: Janauer G.A., Hale P. and Sweeting R. (eds.), Macrophyte inventory of the river Danube: A pilot study, Arch. Hydrobiol., Suppl. 147, Large Rivers, 14, 9-16.

Janauer G.A. nad Dokulil M., 2006. Macrophytes and algae in running waters. In: Ziglio G., Siligardi M. and Flaim G. (eds.), Biological monitoring of rivers, John Wiley \& Sons, Chichester, 89-109.

Janauer G.A., Schmidt-Mumm U., Schmidt B., 2010. Aquatic macrophytes and water current velocity in the Danube River. Ecol. Eng., 36, 1138-1145.

Lacoul P. and Freedman B., 2006. Environmental influences on aquatic plants in freshwater ecosystems. Environ. Rev., 14, 89-136.

Lepš J. and Šmilauer P., 2007. Multivariate analysis of ecological data using CANOCO (third printing). Cambridge University Press, Cambridge, $272 \mathrm{p}$.

Manolaki P. and Papastergiadou E., 2013. The impact of environmental factors on the distribution pattern of aquatic macrophytes in a middle-sized Mediterranean stream. Aquat. Bot., 104, 34-46.

Marhold K. and Hindák F., 1998. Zoznam nižších a vyšších rastlín Slovenska. Veda, Bratislava, 688 p.

Meyers L.S., Gamst G. and Guarino A.J., 2006. Applied multivariete research: design and interpretation. Sage Publications, London, $722 \mathrm{p}$.

Miklos L., 2002. Atlas krajiny Slovenskej republiky. 1. vydanie. Ministerstvo životného prostredia Slovenskej republiky, Bratislava and Slovenská agentúra životného prostredia, Banská Bystrica, $344 \mathrm{p}$.

O'Hare M., Baatrup-Pedersen A., Nijboer R., Szoszkiewicz K. and Ferreira T., 2006. Macrophyte communities of European streams with altered physical habitats. Hydrobiologia, 566, 197-210.

Onaindia M., Amezaga I., Garbisu C. and Garcia-Bikuña B., 2005. Aquatic macrophytes as biological indicators of environmental conditions of rivers in north-eastern Spain. Ann. Limnol. - Int. J. Limn., $41,175-182$.

Ot'ahel'ová H., 1995a. Lemnetea de Bolós et Masclans 1955. In: Valachovič M. (ed.), Rastlinné spoločenstvá Slovenska 1. Pionierska vegetácia, Veda, Bratislava, 129-150.

Ot'ahel'ová H., 1995b. Potametea R. Tx. et Preising 1942. In: Valachovič M. (ed.), Rastlinné spoločlenstvá Slovenska 1. Pionierska vegetácia, Veda, Bratislava, 151-179.

Ot'ahel'ová H. and Ot'ahel' J., 2006. Distribution of aquatic macrophytes in pit lakes in relation to the environment (Borská nížina lowland, Slovakia). Ekológia, 25, 398-411.

Ot'ahel'ová H., Janauer G.A. and Husák Š., 1994. Beitrag Zur Wasser- und Sumpfvegetation im Marchinundationsgebiet (Slowakei). Ekológia, Suppl. 1/1994, 43-54.

Ot'ahel'ová H., Valachovič M. and Hrivnák R., 2007. The impact of environmental factors on the distribution pattern of aquatic plants along the Danube River corridor (Slovakia). Limnologica, 37, 290-302.

Paal J., Trei T. and Viik M., 2007. Vegetation of Estonian watercourses, III. Drainage basins of the Moonsund Sea, the Gulf of Riga and Saaremaa Island. Ann. Bot. Fennici, 44, 321-344.

Rahbek C., 1995 The elevational gradient of species richness: a uniform pattern? Ecography, 18, 200-205.

Riis T., Sand-Jensen K. and Vestergaard O., 2000. Plant communities in lowland Danish sterams: species composition and environmental factors. Aquat. Bot., 66, 255-272. 
Rodriguez J.B., Self J.R. and Soltanpour P.N., 1994. Optimal conditions for phosphorus analysis by the ascorbic acid-molybdenum blue method. Soil Sci. Soc. Am. J., 58, 866-870.

Sârbu A., Janauer G.A., Schmidt-Mumm U., Filzmoser P., Smarandache D. nad Pascale G., 2011. Characterisation of the potamal Danube River and the Delta: connectivity determines indicative macropyhte assemblages. Hydrobiologia, 671, 75-93.

StatSoft, 2001. STATISTICA. System reference. StatSoft Inc., Tulsa.

Svitok M., Hrivnák R., Ot’ahel'ová H., Dúbravková D., Pal'ove-Balang P. and Slobodník V., 2011. The importance of local and regional factors on the vegetation of created wetlands in Central Europe. Wetlands, 31, 663-674.

ter Braak C.J.F. and Šmilauer P., 2002. CANOCO Reference manual and CanoDraw for Windows User's guide. Software for Canonical Community Ordination (version 4.5). Microcomputer Power, Ithaca.

Tockner K., Schiemer F., Baumgartner C., Kum G., Weigand E., Zweimüller I. and Ward J.V. 1999. The Danube restoration project: species diversity patterns across connectivity gradients in the floodplain system. Regul. Rivers: Res. Mgmt., 15, 245-258.

Toivonen H. and Huttunen P., 1995. Aquatic macrophytes and ecological gradients in 57 small lakes in southern Finland. Aquat. Bot., 51, 197-221.

Ward J.V. and Tockner K. 2001. Biodiversity: towards a unifying theme for river ecology. Freshwater Biol., 46, 807-819.

Willby N.J., Abernethy V.J. and Demars B.O.L., 2000. Attribute-based classification of European hydrophytes and its relationship to habitat utilization. Freshwater Biol., 43, 43-74.

Williams P., Whitfield M., Biggs J., Bray S., Fox G., Nicolet P. and Sear D., 2004. Comparative biodiversity of rivers, streams, ditches and ponds in an agricultural landscape in Southern England. Biol. Conserv., 115, 329-341. 